\title{
Alpine ocean seafloor spreading and onset of pelagic sedimentation: new radiolarian data from the Chenaillet-Montgenèvre ophiolite (French-Italian Alps)
}

\author{
Fabrice Cordey *, Anthony Bailly \\ UMR 5125 Paléoenvironnements et Paléobiosphère, CNRS, Université Lyon 1, Campus de La Doua, Bt. Géode, 69622 Villeurbanne cedex, France.
}

Received: 14/06/06, accepted: 01/02/07

\begin{abstract}
Radiolarians of Middle Jurassic age (tentatively middle Bathonian) provide the first direct age determination from oceanic sediments associated with the Chenaillet-Montgenèvre ophiolite (Piemonte zone, French-Italian Alps). This datum obtained from radiolarites of the Lago NeroReplatte thrust sheet is older than those previously established on ophiolite sedimentary covers from this segment of the western Alps. It also shows that Lago Nero-Replatte basal radiolarites are anterior to the youngest intrusives from the overlying Chenaillet s.s. thrust sheet. This chronological relationship implies either a late seafloor spreading-related magmatic activity in places younger than adjacent initial pelagic sedimentation, or more likely that the Lago Nero-Replatte and the Chenaillet s.s. thrust sheets are distinct and distant pieces of lithosphere that were eventually stacked together: the Lago Nero-Replatte unit was trapped within the accretionary wedge while the Chenaillet s.s., of a younger age and in a more distal position with regards to the European margin, was obducted. Regionally, the Lago Nero-Replatte sediments appear to be coeval to other Bathonian supraophiolitic radiolarites exposed in the western Alps. These results strengthen the Bathonian correlation of widespread seafloor spreading in both western Tethys and the central Atlantic ocean.
\end{abstract}

(C) 2007 Lavoisier SAS. All rights reserved

Keywords: ophiolite, radiolarite, Chenaillet-Montgenèvre, Lago Nero-Replatte, western Alps, seafloor spreading

\section{Introduction}

Located within the Piemonte zone straddling the French-Italian border, the Chenaillet-Montgenèvre massif is a well-known preserved ophiolite body from the western Alps (Fig 1). It is traditionally considered as a remnant of embryonic crust related to an Atlantic-type low-spreading center [1-4] and has been the focus of numerous studies over the last 30 years including recent models of ocean magmatism and seafloor spreading [5-7]. It is also a classical Alpine destination for academic excursions and field schools $[8,9]$. However, no local age control from these various units was documented until recently. Radiometric dating was achieved on Chenaillet gabbros and intrusives by Costa and
Caby [10] but sedimentary rocks from the area were still devoid of direct age control due to the technical difficulties of extracting diagnostic microfossils from metasediments. Remarkably, radiolarians from the Mongenèvre area were initially studied in thin sections by Italian paleontologists more than a century ago: in 1890, Parona documented a radiolarian fauna from the siliceous schists of Cesana [11] while in 1912 Squinabol described an assemblage interpreted at the time as latest Jurassic in age [12]. However, no direct reliable age determination was ever produced on radiolarian chert from the area nor from the Briançon map sheet [13] in spite of several attempts.

\footnotetext{
* Corresponding author

Tel: +33 (0)4 72448374 - Fax: +33 (0)4 72448382

E-mail address: fabrice.cordey@univ-lyon1.fr
} 
Fig. 1:

Location of study area.

A: main mountain

ranges of SW Europe.

B: SW Alps and main

structural zones of the

French-Italian segment.

C: location of the

Chenaillet-Montgenèvre

ophiolite across the

French-Italian border (from [35])
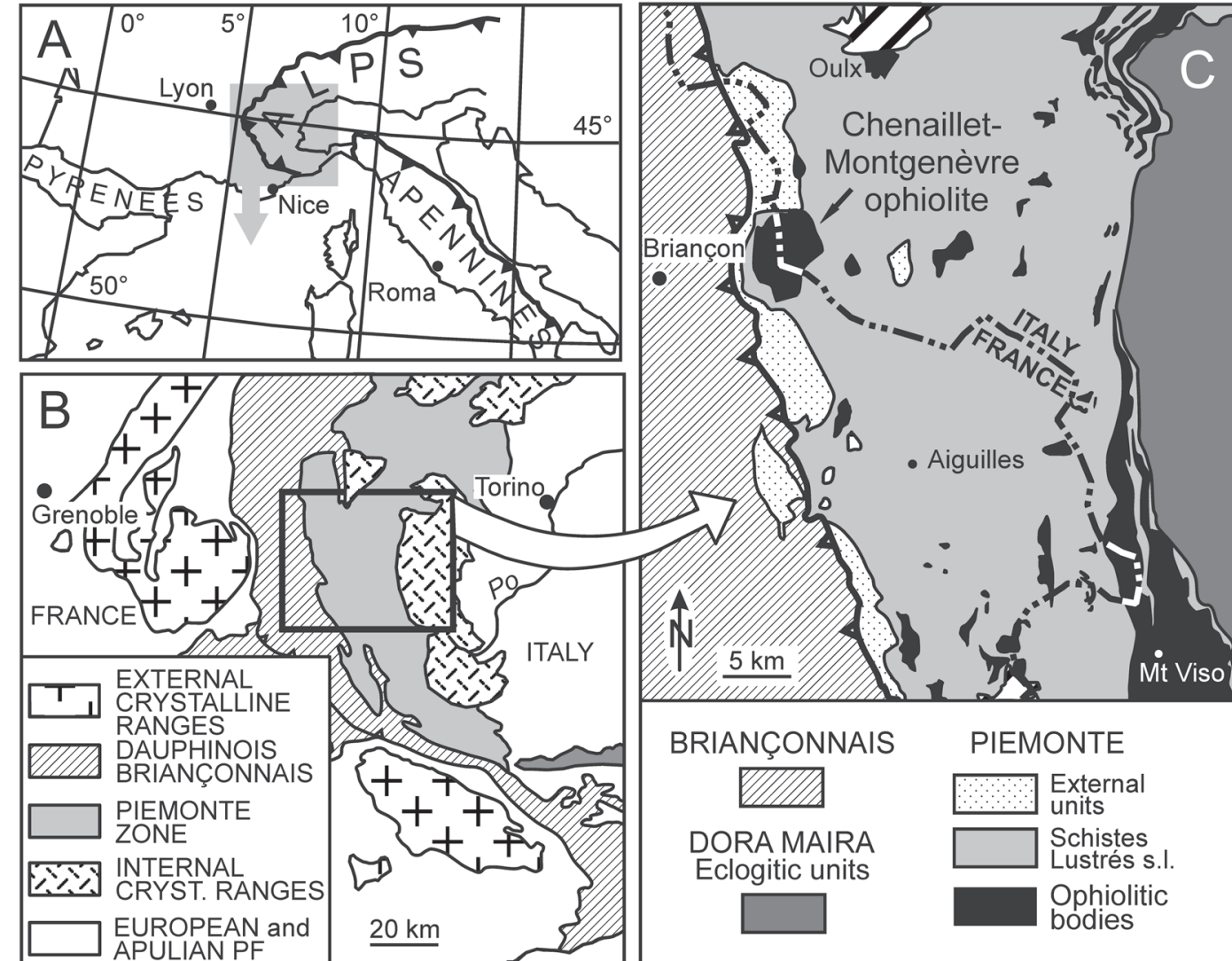

As an additional effort, we chose to apply specific radiolarian investigation techniques previously developed on highly disrupted accretionary complexes $[14,15]$, an approach which eventually led to the recovery of one diagnostic radiolarian assemblage. The corresponding age determination will be compared with local radiometric data as well as previous results obtained from radiolarites of the Piemonte zone. These data will then be discussed within a broader regional Alpine setting and compared with the timing of seafloor spreading in the central Atlantic ocean.

\section{Geological setting}

The Chenaillet-Montgenèvre ophiolite is composed of two main tectonic units. The Chenaillet sensu stricto (s.s.) upper thrust sheet (Fig. 2) comprises low metamorphic grade mafics and ultramafics including exposures of contact between crust and mantle rocks as well as spectacular pillowbasaltic flows; it is devoid of well-developed sedimentary cover due to post-obduction erosion. This upper thrust sheet overlies the Lago Nero-Replatte lower thrust sheet (Fig. 2) composed of ultramafics, mafics and sediments such as radiolarites, ophicalcites (sedimentary breccias with serpentinite clasts and carbonate matrix) and calcschists (metamorphosed marls). This unit carries stratigraphic and metamorphic affinities with the blueschist-bearing "Schistes
Lustrés" complex interpreted as the regional sedimentary cover associated with magmatic rocks and deposited in the Piemonte-Ligurian ocean prior to accretion [16, 17]. Following initial oceanization, the Lago Nero-Replatte sedimentary succession has been inferred as recording an approach towards an accretionary wedge [18].

Within the synthesis about Alpine, Corsican and Apennine ophiolites (ACA) presented by Lagabrielle and Lemoine [4], the upper unit (Chenaillet) is interpreted as derived from a magma-rich (MR) segment of a spreading centre, whereas the lower unit (Lago Nero-Replatte) has been correlated with magma-poor (MP) segment tips of oblique depressions similar to present-day Mid Atlantic Ridge (MAR) spreading centre. Both MR and MP types can be found as superposed tectonic units within one single and complex ophiolite body, not only in the Chenaillet area, but also the Viso massif located to the south-east (Fig. 1C).

\section{Biostratigraphic results}

\subsection{Radiolarite locality}

Within the Chenaillet-Montgenèvre massif, radiolarites are traditionally considered as the base of the sedimentary succession associated with the ophiolite body although, as mentioned above, they occur within the underlying Lago Nero-Replatte thrust sheet (Fig. 2A) on both sides of the 

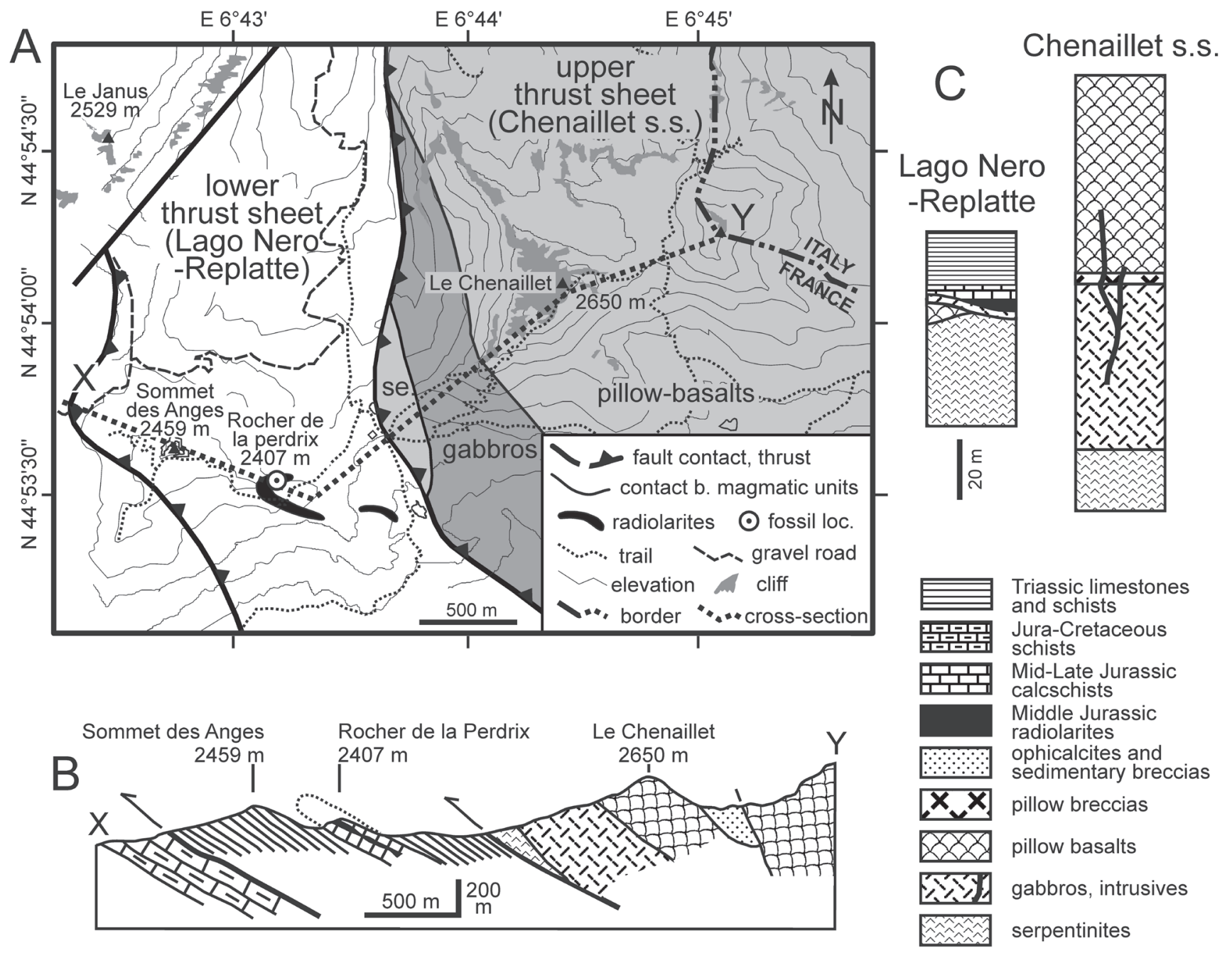

Fig. 2: Geological setting of the western Chenaillet-Montgenèvre area. A: topography and geology (modified from [13]); se: serpentinites; B: X-Y cross-section of Lago Nero-Replatte and Chenaillet thrust sheets. C: schematic sketches of magmatic and stratigraphic relationships within Lago Nero-Replatte and Chenaillet units (from [4]).

border (Italy: Monte Cruzore and Sagna-Longa; France: Gondran). Our study focused on a well-known exposure from the Gondran cirque located on a topographic knob named "Rocher de la perdrix" (Figs. 2, 3) which displays an isoclinal anticline fold structure with a $13 \mathrm{~m}$-thick sequence of sheared red radiolarian chert overlain with calcschists (Fig. 3). Chert beds thicknesses vary significantly from a few $\mathrm{mm}$ to a few $\mathrm{cm}$ along with secondary silicification, small scale chevron folding and tectonic thinning (Fig. 3D). Previous interpretations assumed the radiolarite sequence to be quadrupled, a double isoclinal fold duplicating twice an ophicalcite / radiolarite / calcschists series [8]. Instead, we suggest that radiolarites are only doubled within a single isoclinal fold, as is shown by the fairly good lithofacies symmetry of the succession including the occurrence of green chert (Fig. 3C) and thicker radiolarite beds (Fig. 3E) twice along the $13 \mathrm{~m}$ sequence (Fig. 3B). Radiolarian cherts are also exposed to the north over the Gondran meadow (Fig. 3A) and to the south of the ridge where they are locally in stratigraphic contact with ultramafics (Fig. 2C).

\subsection{Faunal assemblage and relative age}

Twenty-eight radiolarite samples have been selected from local outcrops. Microfossil preservation varies significantly from bed to bed as well as within each single bed, a difficulty requiring vertical and lateral scrutiny. All samples released highly recrystallized and locally flattened radiolarians. From this batch, only one sample turned out with exploitable morphotypes (CHE-017, Fig. 3B) obtained through several chemical processing sessions applying various hydrofluoric acid concentrations (HF 5 to $20 \%$ ) as well as thorough microfossil picking and selection. This sample is located $1.5 \mathrm{~m}$ above the reversed stratigraphic base of the exposed succession.

We use herein the standard Tethyan radiolarian zonation of Baumgartner et al. [19] based on Unitary Associations (UA). Although our fauna is not well-preserved, we consider having identified specimens belonging to morphotypes of the genus Kilinora which bears distinctive cephalic features that are not shared with other Jurassic genera. Two specimens of Kilinora cf. tecta ( (UAZ 5-6) characterized by a grooved 

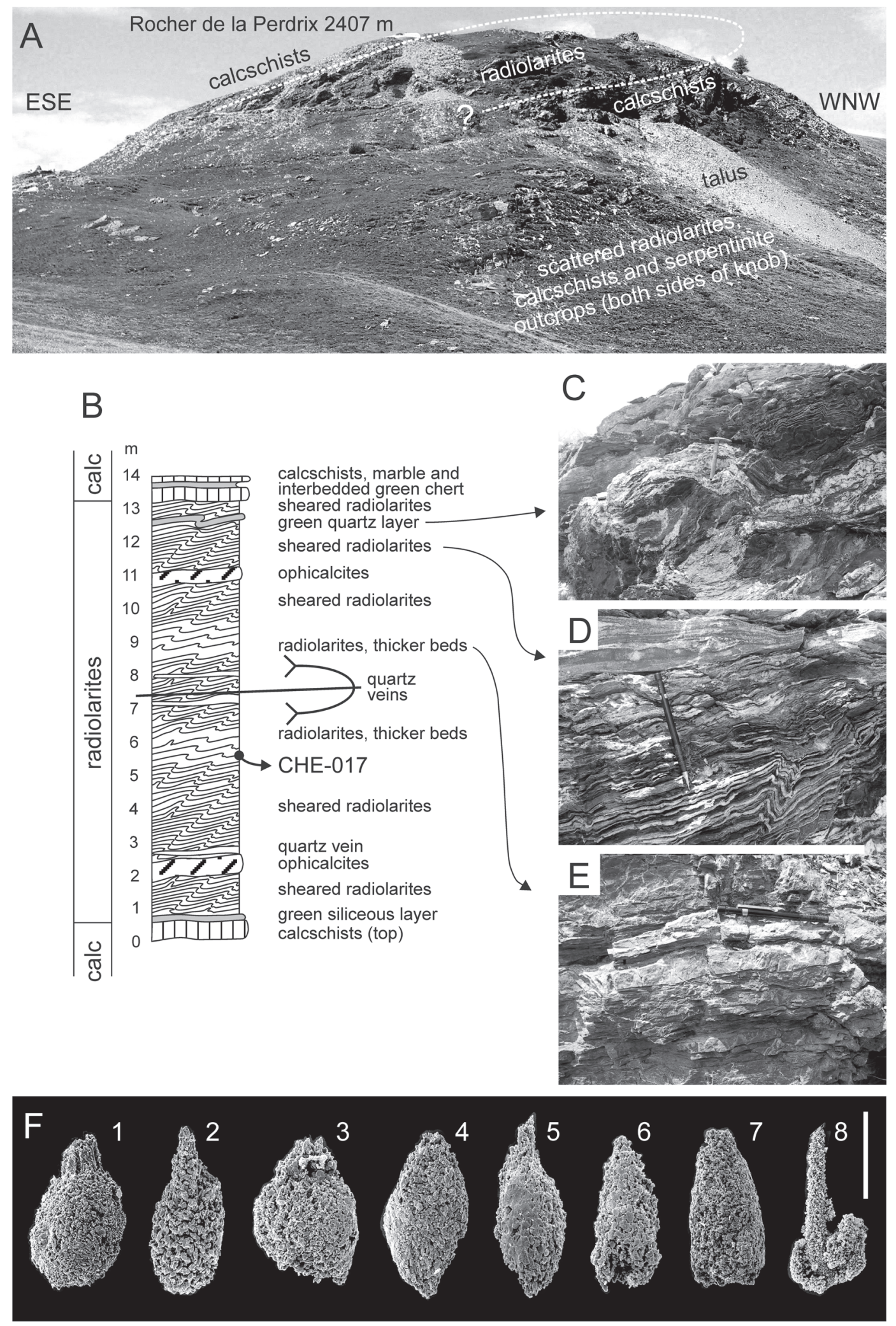

Fig. 3: Radiolarites and microfossil content, locality "Rocher de la perdrix" (Lago Nero-Replatte thrust sheet). A: view to SW from the Gondran cirque and exposures of calcschists and radiolarites (isoclinal fold structure). B: lithostratigraphy of radiolarite succession and location of productive sample CHE-17 (N 44 53'32", E 006 43' 16"; elevation 2385 m); calc: calcschists (= metamorphosed marls). C: contact between calcschists and sheared radiolarian chert $(13 \mathrm{~m})$. D: detail of contact (tip of pencil). E: thicker radiolarian chert beds $(5.5 \mathrm{~m})$. F: radiolarian fauna from sample CHE-17 (taxon, scale bar): 1. Kilinora cf. tecta (Matsuoka), $175 \mu \mathrm{m}$; 2. Kilinora (?) cf. oblongula (Kocher), $125 \mu \mathrm{m}$; 3. Tricolocapsa sp., $120 \mu \mathrm{m}$; 4-5. ? Cyrtocapsa spp., $125 \mu \mathrm{m}, 100 \mu \mathrm{m}$; 6-7. Nassellaria gen. et sp. indet., $100 \mu \mathrm{m}, 150 \mu \mathrm{m} ; 8$. fragment of unidentified spumellarian with spine, $125 \mu \mathrm{m}$. 
cephalis (Fig. 3F) and three specimens of Kilinora (?) cf. oblongula (Kocher) (UAZ 6-8) possessing an elongated cephalic structure, are present within the assemblage along with unidentified nassellarians (Fig. 3F). These taxa overlap within UAZ 6, an assemblage zone correlative with a middle Bathonian age [19]. Some specimens (Fig. 3F, n 3-4) evoke external shapes of Bathonian morphotypes recently described under the name of Helvetocapsa [20] but our material is not well-preserved enough to confirm this attribution.

Although it has been recently observed that UAZ 6 (middle Bathonian) and UAZ 7 (late Bathonian or early Callovian) are in places difficult to differentiate [20], the cooccurrence of Kilinora tecta and $K$. (?) oblongula has been recently documented from Alpine radiolarite localities considered as middle Bathonian in age [20]. It should be noted that $K$. tecta and $K$. (?) oblongula have never been reported from the well-preserved assemblage of late Bathonian or early Callovian age (UAZ 7) from the Traversiera massif [21], suggesting that our assemblage is distinct and older than those previously obtained from radiolarite successions of the Piemonte zone (see details in section 4.2).

\subsection{Depositional environment}

The mafic/ultramafic basement is not exposed at the locality "Le Rocher de la perdrix", but is found $500 \mathrm{~m}$ to the south-east where a series of normal faults forming a succession of panels downslope show that ultramafics (gabbros-serpentinites) are overlain with either radiolarian chert or calcschists. Radiolarites underlie calcschists with variation in thicknesses. Ophicalcites are found interlayered with chert and calcschists as well, implying several events of resedimentation by debris flows. The interlayering of ophicalcites and radiolarites suggests a depositional environment above the CCD along with high rates of biosiliceous input. Western Tethys radiolarites are commonly interpreted as linked to upwellings [22]. However, favourable preservation conditions may also be related to magmatism within the ocean basin [23], an environment materialized by tuffaceous interlayers into radiolarian chert. Along with oceanization, radiolarian deposition at this particular time period may also be related to modifications in global paleooceanographic conditions (see synthesis [24]).

\section{Discussion and interpretation}

\subsection{Age of radiolarites from the Piemonte zone}

Radiolarites from the Chenaillet-Montgenèvre massif were originally considered as Late Jurassic in age based on Squinabol's assessment [12], then by correlation with late Oxfordian-middle Kimmeridgian radiolarians obtained from the "Schistes Lustrés" series near St Véran [25]. This age was later revised with the updated radiolarian biozonation [19] and attributed to the middle or late Oxfordian (UAZ 9) [21]. A second significant radiolarian-bearing locality was found by R. Polino (Y. Lagabrielle, pers. com. 2006) within phosphate nodules at the base of the sedimentary cover of ophiolites from the Traversiera massif. It was firstly dated as late Oxfordian-early Kimmeridgian [26], an age later revised twice [21, 27] and finally stabilized at UAZ 7 (late Bathonian or early Callovian).

Therefore our study suggests that: 1/ ChenailletMontgenèvre radiolarites are older than previously inferred and are restricted to the Middle Jurassic; 2/ the oldest sediments associated with ophiolite material in the French-Italian Alps are Bathonian in age; 3 / these sediments are coeval to wellrepresented Bathonian supraophiolitic radiolarite successions from other localities of the western Alps (same radiolarian biozone UAZ 6 identified in the Gets nappe, French-Swiss Alps [24] and the Balagne nappe, Corsica [28, 29]).

\subsection{Comparison with local radiometric ages and implications}

Geochronological studies on the Chenaillet-Montgenèvre magmatic rocks [10] provide an isochron age of $198 \pm 22 \mathrm{Ma}$ on gabbros, while zircons from a leucodioritic vein within gabbros are $156 \pm 3 \mathrm{Ma}$ and an albitite lens within mantle rocks display concordant ages at $148 \pm 2 \mathrm{Ma}$. Albitites are interpreted as either fractionated mantle-derived magmas of tholeitic character [30] or the final differentiation product of a MORB-type mantle source [10]. These results support the model of asymmetric mantle-denudation by an oblique detachment fault [1] implying that the newly formed lherzolite-gabbro oceanic domain probably remained close to the spreading center and therefore experienced slow cooling and low spreading rates.

Although gabbros are Early Jurassic in age, our study shows that radiolarites of Middle Jurassic age are in fact older than leucodiorite and albitite intrusives (which fit into the OxfordianKimmeridgian interval). Depending on time scales, the base of the Bathonian is set at $164 \pm 2,166^{+0.6 /}{ }_{-0.5}$, or $167.5 \pm 3.7$ ([31-33] respectively), whereas top of stage is $160 \pm 2,160.4$ $+1.1{ }_{-0.5}$ or $164.7 \pm 4$ ([31-33] respectively). Therefore middle Bathonian is broadly equivalent to $\sim 162 \mathrm{Ma} \mathrm{[31],} \mathrm{163} \mathrm{Ma} \mathrm{[32]}$ or $\sim 166 \mathrm{Ma}$ [33]. It means that the minimum age discrepancy between the base of Lago Nero-Replatte radiolarites and the youngest intrusives may reach about 15 m.y..

These results require two distinct hypotheses: 1/ late magmatic activity (intrusives) has crosscut ultramafics and mafics when pelagic deposition was already taking place in the basin, in accordance with slow cooling and spreading rates; $2 /$ the two thrust sheets (Lago Nero-Replatte and Chenaillet s.s.) represent two distinct and diachronous pieces of lithosphere.

Along with the first proposition, a conservative model could account for the regional coexistence of late magmatism and onset of pelagic sedimentation within the same basin. The occurrence of denuded ultramafics and ophicalcites within the two units could suggest that Lago Nero-Replatte may represent a more or less distant lateral equivalent to the Chenaillet s.s.. It has been previously implied that albitite intrusives from the Chenaillet crosscut basalts as well [30], meaning they could 
Fig. 4: Paleogeographic reconstruction of the Alpine Tethys and central Atlantic Ocean in late Middle Jurassic time (based on [24]) with location of middle Bathonian radiolarian-bearing series ( 165 Ma) associated with oceanic crust (stars). TFS: Transfer Fault System; Ba: Balagne; Ch: Chenaillet-Montgenèvre; Ge: Gets. Thick lines: seafloor spreading; grey pattern: oceanic crust.

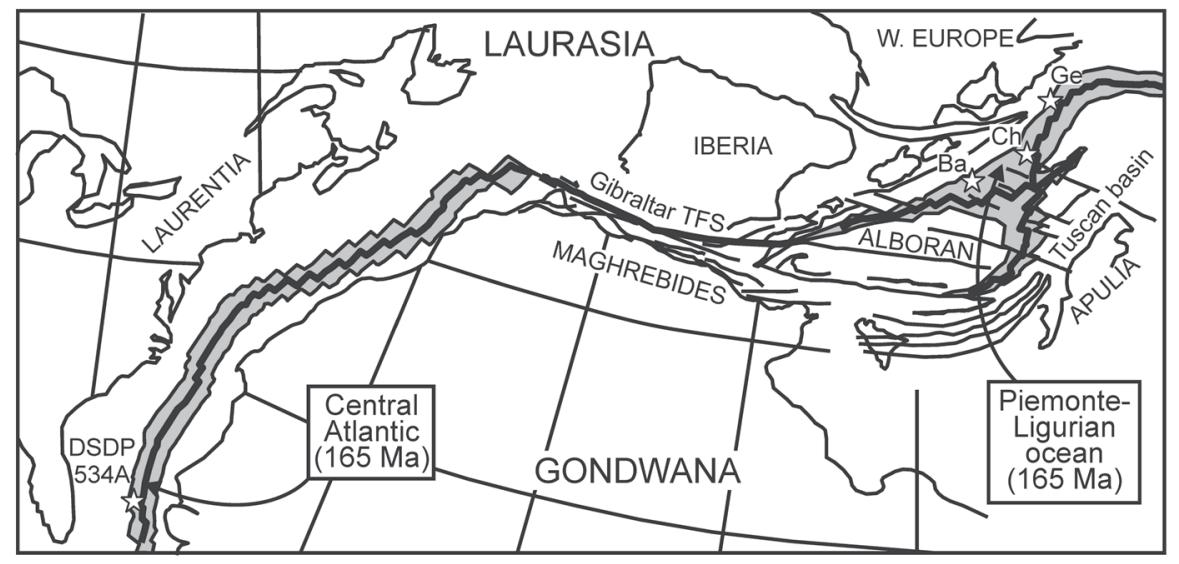

locally be younger than the first sediments deposited on adjacent denuded ultramafics. However, one difficulty with this model lies in the fairly long age discrepancy between the Lago Nero-Replatte radiolarites and the Chenaillet intrusives. This age hierarchy does not only concern our locality: Traversiera radiolarites (late Bathonian-early Callovian in age [21]) which are in a similar structural position on the westernmost part of the Piemonte zone, are also older than the Chenaillet s.s. youngest magmatic rocks [10]. In accordance with our second proposition, authors have previously stressed the differences between the two thrust sheets such as their metamorphic grade and considered that they had a distinct tectonic history [4]. Although radiolarites have never been found within the Chenaillet s.s. unit, we locally observed thin deposits overlying denuded mantle rocks, unfortunately devoid of microfossils. So far as we know, the age difference between the two thrust sheets supports the interpretation that Lago Nero-Replatte and Chenaillet s.s. are distinct and initially distant pieces of lithosphere that were eventually stacked together. In this model, the Lago Nero-Replatte would represent an older and more western oceanic unit trapped within the Alpine accretionary wedge while the younger Chenaillet s.s. thrust sheet, in a more distal location with regards to the European margin, was obducted.

\subsection{Bathonian seafloor spreading from western Tethys and the Atlantic}

The oldest Alpine radiolarites are Bajocian in age (UAZ 3) but are associated with pre-rifting thinned continental margins units (northern Appennines, see synthesis by [24, 29, 34]). A latest Bajocian or early Bathonian age (UAZ 5) is reported from Ligurian radiolarites [29]. As mentioned previously, the more widespread group of radiolarites associated with initial oceanic crust is Bathonian in age (UAZ 6) and is documented in the French-Swiss Alps (Gets nappe [24]) and in Corsica (Balagne nappe [28]; Fig. 4). Our study suggests that the Lago Nero-Replatte succession could be part of this domain. It also means that radiolarites from the Piemonte zone could be more diachronous than previously established (middle Bathonian from this study, late Bathonian-early Callovian from Traversiera, middle-late Oxfordian from St-Véran), reinforcing the interpretation that the corresponding ocean was formed over an extended period of time. As stressed by previous authors [24], Bathonian was a time when siliceous sedimentation became common to the entire Alpine Tethys. Radiolarian-bearing deep sea sedimentation also occurred at the same time in the central Atlantic ocean (Deep Sea Drilling Project leg 76, site 534A). A previous study stressed out that radiolarian faunal similarities between these localities suggest a Bathonian connection between these two major oceanic domains [24].

\section{Conclusion}

Microfossil investigation techniques applied to radiolarites of the Chenaillet-Montgenèvre area (Lago Nero-Replatte unit) result in a new Middle Jurassic biochronological datum. It leads to reassess our traditional interpretation of Lago NeroReplatte vs. Chenaillet s.s. units relationships and reinforces the Bathonian correlation existing between several oceanic remnants of the western Alps. Based on a single radiolarian assemblage, our result probably needs complementary investigations in the vicinity of the study area, for instance on Lago Nero-Replatte radiolarites exposed to the east of the FrenchItalian border. We hope to bring here some renewed prospects towards analyzing the microfossil contents of these metamorphosed Alpine units and their structural implications.

\section{Acknowledgments}

We thank Stéphane Guillot, Jean-Marc Lardeaux, Patrick Ledru, Stéphane Schwartz and Raymond Cirio for fruitful discussions in Lyon and during field school trips to the Chenaillet-Montgenèvre area. Yves Lagabrielle and Patrick De Wever are thanked for their insightful reviews, as well as Jean Van Den Driessche for editorial help. Arlette Armand and Paula Desvignes (CNRS UMR 5125) offered technical support. The Geological Survey of Canada (Pacific Division) provided library assistance while on a sabbatical leave in Vancouver in 2006 (FC) Contribution UMR5125-07.22. 


\section{References}

[1] Lemoine, M., Tricart, P., Boillot, B., Ultramafic and gabbroic: Ocean floor of the Ligurian Tethys (Alps, Corsica, Apennines): In search of a genetic model, Geology 15 (1987) 622-625.

[2] Lagabrielle, Y., Cannat, M., Alpine Jurassic ophiolites resemble the modern central Atlantic basement, Geology 18 (1990) 319-322.

[3] Caby, R., Plastic deformation of gabbros in a slow-spreading Mesozoic ridge: Example of the Mongenèvre Ophiolite, western Alps, in: Vissers, R.L.M., and Nicolas, A. (Eds.), Mantle and lower crust exposed in oceanic ridges and in ophiolites, Norwell, Massachusetts, Kluwer Academic, 1995, pp. 123-145.

[4] Lagabrielle, Y., Lemoine, M., Alpine, Corsican and Apennine ophiolites : the slow-spreading ridge model, C. R. Acad. Sci. Paris 325 (1997) 909-920.

[5] Edel, J.-B., Peron-Pinvidic, G., Manatschal, G., Mantle exhumation processes and later tectonic evolution of the Chenaillet ophiolite - preliminary magnetic anisotropy and paleomagnetic data, AGU-EUG Joint Assembly, Nice (2003) abstract 4851.

[6] Chalot-Prat, F., An undeformed ophiolite in the Alps: Field and geochemical evidence for a link between volcanism and shallow plate tectonic processes, Geol. Soc. Am. Spec. Paper 388 (2005) 751-780.

[7] Manatschal, G., Müntener, O., Lagabrielle, Y., The Chenaillet ophiolite: a fossil oceanic core complex?, Geophys. Res. Abs., EUG-EGS, Vienna (2005) A164.

[8] Lemoine, M., Cirio, R., Pellet, G., Keck, R., Le massif du Chenaillet (Montgenèvre, Alpes Franco-italiennes), Ed. Centre Briançon. Géol. Alp., Briançon, 1995, 96 p.

[9] Winterflood, I., An excursion in the French-Italian Alps: the 'Atlantic'-type ophiolite at Mont Chenaillet, Geol. Today 17 (2001) 143-148.

[10] Costa, S., Caby, R., Evolution of the Ligurian Tethys in the Western Alps: $\mathrm{Sm} / \mathrm{Nd}$ and $\mathrm{U} / \mathrm{Pb}$ geochronology and rare-earth element geochemistry of the Montgenèvre ophiolite (France), Chem. Geol. 175 (2001) 449-466.

[11] Parona, C. F., Sugli schisti silicei a radiolarie di Cesana presso il Monginevra. Atti della reale Accademie delle Scienze di Torino, 27 (1890) 305-319.

[12] Squinabol, S., Radiolari della strada nazionale al Monginervo. Bollettino del reale Comitato geologico d'Italia, 43, 2-3 (1912) 281-289.

[13] Bartéfy, J.C., Lemoine, M., Mercier, D., Polino, R., Nievergelt, P., Bertrand, J., Dumont, T., Amaudric du Chaffaut, S., Pêcher, A., Monjuvent, G., Carte géologique de France (1/50 000), feuille Briançon 823, Bur. Rech. Géol. Min., Orléans, 1996.

[14] Cordey, F., Krauss, P., A field technique for identifying and dating radiolaria applied to British Columbia and Yukon, Geol. Surv. Canada Paper 90-1E (1990) 127-129.

[15] Cordey, F., Radiolaires des complexes d'accrétion cordillérains, Geol. Surv. Canada Bull. 509, 1998, 210 p.

[16] Deville, E., Fudral, S., Lagabrielle, Y., Marthaler, M., Sartori, S., From oceanic closure to continental collision; a synthesis of the «schistes lustrés» metamorphic complex of the Western Alps, Geol. Soc. Am. Bull. 104 (1992) 127-139.

[17] Schwartz, S., La zone Piémontaise des Alpes occidentales: un paléocomplexe de subduction, thèse univ. Lyon, 2000, 350 p.
[18] Burroni, A., Levi, N., Marroni, M., Pandolfi, L., Lithostratigraphy and structure of the Lago Nero unit (Chenaillet massif, western Alps): comparison with internal liguride units of northern Apennines, Ofioliti 28-1 (2003) 1-11.

[19] Baumgartner, P.O., Bartolini, A., Carter, E.S., Conti, M., Cortese, G., Danelian, T., De Wever, P., Dumitrica, P., Dumitrica-Jud, R., Gorican, S., Guex, J., Hull, D.M., Kito, N., Marcucci, M., Matsuoka, A., Murchey, B., O’Dogherty, L., Savary, J., Vishnevskaya, V., Widz, D., Yao, A., Middle Jurassic to Early Cretaceous radiolarian biochronology of Tethys based on unitary associations, in: Baumgartner, P.O., et al. (Eds.), Middle Jurassic to Lower Cretaceous Radiolaria of Tethys: Occurrences, systematics, biochronology, Mém. Géol. 23, Lausanne, 1995, pp. 1013-1043.

[20] O’Dogherty, L., Bill, M., Gorican, S., Dumitrica, P., Masson, H., Bathonian radiolarians from an ophiolitic mélange of the Alpine Tethys (Gets Nappe, Swiss-French Alps), Micropaleontology 51 (2006) 425-485.

[21] De Wever, P., Baumgartner, P.O., Radiolarians from the base of the supra-ophiolitic Schistes Lustrés Formation in the Alps (Saint-Véran, France and Traversiera Massif, Italy), in: Baumgartner, P.O., et al. (Eds.), Middle Jurassic to Lower Cretaceous Radiolaria of Tethys: occurrences, systematics, biochronology, Mém. Géol. 23, Lausanne, 1995, pp. 725-730.

[22] De Wever, P., Azéma, J., Fourcade, E., Radiolaires et radiolarites: production primaire, diagenèse et paléogéographie, Bull. Ctr. Rech. Expl. Prod. Elf Aquitaine 18 (1994) 315-379.

[23] Racki, G., Cordey, F., Radiolarian paleoecology and radiolarites: is the present the key to the past ?, Earth Sc. Rev. 52 (2000) 83-120.

[24] Bill, M., O’Dogherty, L., Guex, J., Baumgartner, P.O., Masson, H., Radiolarite ages in Alpine-Mediterranean ophiolites: Constraints on the oceanic spreading and the Tethys-Atlantic connection, Geol. Soc. Am. Bull. 113 (2001) 129-43.

[25] De Wever, P., Caby, R., Datation de la base des Schistes lustrés postophiolitiques par des radiolaires (Oxfordien supérieur-Kimméridgien moyen) dans les Alpes Cottiennes (Saint-Véran, France), C. R. Acad. Sci. Paris 292 (1981) 467-472.

[26] Schaaf, A., Polino, R., Lagabrielle, Y., Nouvelle découverte de radiolaires d'âge Oxfordien supérieur-Kimmeridgien inférieur, à la base d'une série supra-ophiolitique des Schistes Lustrés piémontais (Massif de Traversiera, Haut Val Maïra, Italie), C. R. Acad. Sc. Paris 301-II, 14 (1985), 1079-1084.

[27] De Wever, P., Baumgartner, P.O., Polino, R., Précision sur les datations de la base des Schistes Lustrés postophiolitiques dans les Alpes Cottiennes, C. R. Acad. Sc. Paris 305-II, (1987), 487-491.

[28] De Wever, P., Danelian, T., Durand-Delga, M., Cordey, F., Kito, N., Datations des radiolarites post-ophiolitiques de Corse alpine à l'aide des Radiolaires, C. R. Acad. Sci. Paris 305 (1987) 893-900.

[29] Chiari, M., Marcucci, M., Principi, G., The age of the radiolarian cherts associated with the ophiolites in the Apennines (Italy) and Corsica (France): a revision, Ofioliti 25-2 (2000) 141-146.

[30] Chapelle, B., La lithosphère océanique de la Téthys ligure. Etude des magmatismes basiques et acides (massifs ophiolitiques du Montgenèvre et de Haute Ubaye), thèse univ. Grenoble, 1990, 196 p. 
[31] Odin, G.S., Geological time scale, C. R. Acad. Sci. Paris 318 (1994) 59-71.

[32] Pálfy, J., Smith, P.L., Mortensen, J.K., A U-Pb and ${ }^{40} \mathrm{Ar} /{ }^{39} \mathrm{Ar}$ time scale for the Jurassic, Can. J. Earth Sc. 37 (2000) 923-944.

[33] Gradstein, F.M., Ogg, J.G., Smith, A.G., et al., A Geologic Time Scale, Cambridge Univ. Press, 2004, 589 p..
[34] Bortolotti, V., Principi, G., Tethyan ophiolites and Pangea break-up, Island Arc 14 (2005) 442-470.

[35] Schwartz, S., Allemand, P., Guillot, S., Numerical model of the effect of serpentinites on the exhumation of eclogitic rocks: insights from the Monviso ophiolitic massif (Western Alps), Tectonophysics 342 (2001) 193-206. 